\title{
Skin Protective Nutraceuticals: The Current Evidence in Brief
}

\section{Oroma Nwanodi (iD}

Obstetrics and Gynecology Locum Tenens, Salinas, CA 93902, USA; o.nwanodi@juno.com; Tel.: +1-314-304-2946

Received: 17 March 2018; Accepted: 1 May 2018; Published: 4 May 2018

\begin{abstract}
Nutraceuticals are important for healthy skin maintenance. Probiotics, phenolics, and vitamins are just a few of the nutraceuticals meant to potentially prevent and assist medical management of dermatologic conditions. Among these, probiotics, vitamin E, and green tea catechins may offer the broadest array of skin protective mechanisms with probiotics having the greatest clinical range. Probiotics' amelioration of atopic dermatitis and opportunistic infections of skin burns has been targeted in recent research efforts. This includes the improvement of Scoring Atopic Dermatitis index scores, $p=0.02$, with intact Lactobacillus rhamnosus Goldin and Gorbach (LGG) in comparison to heat inactivated LGG or placebo. Lactobacillus reuteri used prior to or concurrently with Staphylococcus aureus infection can increase epidermal keratinocyte survival, $p<0.01$. Phenolics may not have been extensively studied for atopic dermatitis or skin burns. However, phenolics do have a role in photoprotection. The phenolic rutin increases ultraviolet $B$ radiation filter reactive oxygen species scavenging at $75 \%, p<0.002$, and peak wavelength absorption, $p<0.001$. While oral and topical probiotics have untapped potential for atopic dermatitis amelioration and skin infection prevention, phenolics will be increasingly used for photoprotection. With optimized bioavailability, dosage, and formulation, nutraceuticals will become crucial for healthy skin maintenance.
\end{abstract}

Keywords: atopic dermatitis; green tea; human skin; keratinocyte; moisturizer; nutraceuticals; photoprotection; polyphenols; probiotics; vitamin E

\section{Introduction}

Nonmelanoma skin cancers (NMSC), which are comprised primarily of basal cell carcinomas (BCC) and squamous cell carcinomas (SCC), are one of the most common human cancers with an 18-fold to 20-fold higher incidence than melanoma [1,2]. Therefore, photocarginogenesis prevention is important. Global NMSC incidence varies. BCC is most common in Australia and the United States of America (USA) at more than 1000 and 450 per 100,000 person-years, respectively [2]. BCC is the least documented in Africa at less than 1 per 100,000 person-years [3]. Meanwhile, SCC occur at one-third the rate of BCC, which amounts to 22.65 per 100,000 person-years in England [2,3]. Annually, at least 1.3 million NMSC occur in the USA, affecting one in five Americans and costing more than $\$ 650$ million USD [4]. The skin, which is a multifunctioning organ, is the innate photocarginogenesis prevention organ. The skin controls body temperature and water content, which prevents dryness. The skin protects the covered body from infection, physical damage, and ultraviolet radiation (UVR) [5]. Damage to the skin occurs via several modalities including heat, moisture, UVR, and direct mechanical trauma. UVR from a $200 \mathrm{~nm}$ to $400 \mathrm{~nm}$ spectrum has dose-dependent photo-carcinogenic and photo-damaging effects including immunosuppression, UVR-dependent acute inflammation with dermal leukocytic infiltrate, and erythema (sunburn) [6]. Acute inflammation induces cytosolic phospholipase A2, which increases free arachidonic acid, the substrate for eicosanoid production by cyclooxygenases and lipoxygenases, and leads to prostaglandin E2 (PGE2) and 
12-lipoxygenase-derived 12-hydroxyeicosatetraenoicacid (HETE), which are the two primary actors in a sunburn [6].

Ultraviolet A radiation (UVA), which has a $320 \mathrm{~nm}$ to $400 \mathrm{~nm}$ spectrum range, is the deepest penetrating UVR at $1000 \mu \mathrm{m}$ into the epidermis and dermis and comprises $90 \%$ to $95 \%$ of UVR [1]. UVA dysregulates melanogenesis via oxidative stress induction and antioxidant defense impairment while ultraviolet B radiation (UVB) and ultraviolet C radiation (UVC) directly damages DNA [1,7]. UVA activates melanogenesis, increases tyrosinase concentration and activity, and increases reactive oxygen species (ROS) and 8-hydroxy-2'-deoxyguanosine (8-OHdG) while reducing glutathione S-transferase (GST) [7]. Within one hour after exposure, UVA is associated with a decreased nuclear factor E2-related factor 2 (Nrf2) nuclear translocation and transcriptional activity. UVA exposure is associated with glutamate cysteine ligase catalytic subunit (GCLC), GST, and nicotinamide adenine dinucleotide phosphate quinone oxidoreductase 1 (NQO1) downregulation. UVA suppression of extracellular signal-related kinases (ERK), Jun nuclear kinase (JNK), and p38 mitogen-activated protein kinases (MAPK) concurrently decreases Nrf2 nuclear translocation [7].

Keratinocytes are the major cells of the epidermis, which is the outermost skin layer [8]. The most differentiated keratinocytes are found in the stratum corneum outer horny layer and least differentiated keratinocytes are found in the stratum basale closest to the dermis [8]. Being primarily connective tissue, the dermis contains collagen, elastin, fibroblasts, and immune cells [8]. The underlying hypodermis provides vascular and neural networks to the dermis and epidermis [8]. An intact stratum corneum-outer horny skin layer-is elastic and hydrated. Cracking, pruritus, and scaling are signs of a dehydrated, inelastic, damaged outer horny skin layer, which is a skin barrier disorder.

Increased outer horny skin layer thickness is associated with atopic dermatitis (eczema; AD) [5]. About $14 \%$ of children under four years of age have AD [9]. Globally, up to $20 \%$ of persons may experience AD in their lifetime [10]. Annually in the USA, AD costs about \$1 billion USD [10]. Externally applied moisturizers improve dry skin's barrier function and reduce inflammation, which forms part of AD treatment [5,9]. Skin barrier disorders such as AD also have immunologic components [5]. Extrinsic or allergic AD accounts for up to $80 \%$ of AD and involves $\operatorname{IgA}, \operatorname{IgE}$, and regulatory T-cells [9]. The hygiene hypothesis posits that the cleanliness-based lack of antigen exposure decreases self-reactive T-cell suppression, leading to increased autoimmunity and immunologic system-based disorders and includes atopic dermatitis [11,12]. The revised hygiene hypothesis is more specific, linking early childhood impaired immune system development and the hygiene hypothesis with an altered intestinal microbiome. This, in turn, increases allergic and autoimmune disease susceptibility [11,12]. Consistent with the hygiene hypothesis, decreased microbial antigen exposure as an AD risk factor has been strengthened by the association of filaggrin mutation and increased Staphylococcus aureus in $42 \%$ of AD patients [10]. Consistent with the revised hygiene hypothesis' importance of the intestinal microbiome composition, breastfeeding has been associated with a $54 \%$ reduction in $\mathrm{AD}$ for 13,557 term infants [12,13]. In contrast to formula-fed children, breast-fed children have a Bifidiobacterium (Acintobacteria)-based intestinal microbiome [12,13].

Although Hippocrates publicized foods' medicinal value, nutraceutical is a twentieth century term [14]. Based on the European Nutraceutical Association definition, nutraceuticals are naturally occurring, non-toxic, bioactive compounds from animal, microbial, and plant sources that have disease prevention, health promotion, or medicinal properties $[14,15]$. While nutraceuticals can offer an alternative to synthetic pharmaceuticals, in addition to being components of nutritive, functional foods, nutraceuticals may be used as pharmaceutical formulations [14,15]. Particularly when consumed as foods, nutraceuticals may have lower bioavailability and poorer tissue distribution than pharmaceuticals [14]. Nutraceuticals are most effective when hepatic phase II detoxification metabolism and the gastrointestinal microbiota function appropriately $[14,16]$. Numerous skin protective nutraceutical categories exist. The focus henceforth will be on probiotics, polyphenols, and vitamins. The literature for aesthetic skin nutraceuticals contains several other categories including carotenoids, organosulfurs, 
polysaccharides, polyunsaturated fatty acids, quinones, and retinoids. Of these, carotenoids and polyunsaturated fatty acids will be succinctly mentioned [4,17].

\section{Probiotics}

Long-term skin commensal microbiome stability dominated by the Actinobacteria Propionibacterium and Corynebacterium, Firmicutes Staphylococcus, Proteobacteria and Bacteroidetes is achieved in childhood [10]. Skin commensals directly protect against pathogenic microbes and modulate type 1 T-helper (Th1) and type 2 T-helper (Th2) mediated immune responses [10]. Skin commensals' composition is varied in $\mathrm{AD}$ [10]. Stable S. aureus colonization with less than $10^{6} \mathrm{cfu} / \mathrm{cm}^{2}$ of skin occurs in $20 \%$ of people and intermittent carriage occurs in $60 \%$ of people $[8,18]$. Normally, S. aureus at greater than or equal to $10^{6} \mathrm{cfu} / \mathrm{cm}^{2}$ of skin is considered an infection [8]. However, in heat damaged (burned) skin as well as in cracked, dehydrated AD skin, S. aureus causes dose dependently severe opportunistic infections from $10^{5} \mathrm{cfu} / \mathrm{mL}$ or greater [18]. Therefore, $80 \%$ of people are at risk of opportunistic $S$. aureus infections with any skin barrier disruption, which occurs with burns, AD, and acne vulgaris [18]. In addition, altered skin commensal bacterial microflora are associated with $\mathrm{AD}$ and acne vulgaris [18].

Probiotics are live, active, microbial cultures that are generally regarded as safe (GRAS) when consumed in quantities that achieve health benefits to the host $[8,9]$. Heat-inactivated or killed bacteria are not probiotics. Probiotics have not shown any benefit that improves preterm infants' gastrointestinal barrier function and overall health [19]. Probiotics neutralize pathogenic microbes by enhancing hosts' mucin secretions that trap pathogens by acid and bacteriocin secretion as well as by increasing ceramide production without harming the host $[8,20,21]$. Probiotics also protect from pathogenic microbes through competitive exclusion at cell receptor binding sites and competitive nutrient consumption [8,18]. Probiotics can modify and regulate host innate immune responses for additional protection against pathogenic bacteria [8]. Probiotic lactobacilli including Lactobacillus plantarum have shown nonspecific immune system boosting and regulation $[5,20]$. Lactobacilli protect phagocytes from pathogen-directed apoptosis [20]. Therefore, probiotics perform the same anti-pathogenic and anti-inflammatory immunologic functions as the skin commensal microbiome. As such, it is biologically plausible that, when the skin commensal microbiome composition is changed in AD and heat damaged skin, probiotics can function in lieu of the normal skin commensal microbiome.

Historically, with oral formulations, probiotics had to survive gastric transport, adhere to, and colonize the gastrointestinal tract [21]. These criteria are redundant for topically applied probiotics. A topical combination of Lactobacillus paracasei and Bifidobacterium longum reuter reportedly decreased leg dryness and facial roughness in 33 adult females over an eight-week trial [8]. Subsequently, a 66-female double-blind, placebo-controlled, randomized trial of $B$. longum reuter lysate (disrupted bacteria) topically applied to reactive skin twice daily for two months achieved increased skin barrier resistance measured by reduced trans-epidermal water loss (TEWL) and reduced skin sensitivity and dryness in response to thermal and chemical physical changes [22].

Based on a meta-analysis of 19 trials totaling 4076 intervention and 3700 control events, respectively, maternal probiotic consumption in late pregnancy and, during lactation, could reduce $\mathrm{AD}$ incidence in children younger than five years old, Risk Ratio $0.78,95 \%$ Confidence Interval (CI) 0.68 to 0.90, $\mathrm{I}^{2}=61 \%$, Absolute Risk Reduction 44 cases per 1000 children; 95\% CI 20 to 64 [23]. A systematic review of 12 case-control studies on probiotics' effect in pediatric AD patients in Europe and Australia found probiotics to be beneficial [9]. Nine of the included studies showed an association between probiotic use and reduced infections, improved immune response, and reduced gastrointestinal inflammation [9]. Lactobacillus rhamnosus Goldin and Gorbach (LGG), when not heat inactivated, significantly improves the Scoring Atopic Dermatitis index (SCORAD) scores in comparison to heat inactivated LGG or the placebo, $p=0.02$ [9]. LGG also improves SCORAD scores in IgE-sensitized AD patients, $p=0.036$ [9]. A placebo-controlled trial of $1 \times 10^{9} \mathrm{cfu}$, oral Lactobacillus fermentum VRI-033 PCC, twice daily for 8-weeks achieved SCORAD improvements with sustained T-helper 1 IFN- $\gamma$ 
responses, $p=0.046$ for 2 -months post-treatment, which were directly proportional to the SCORAD score improvement [9]. However, L. fermentum VRI-003 use was not associated with reduced topical corticosteroid use [9].

A Lactobacillus salivarius synbiotic (probiotic with prebiotics to increase probiotic delivery) was trialed against prebiotic only in sixty 2- to 14-year-old children with moderate to severe AD [10]. At eight weeks and 10 weeks, L. salivarius synbiotic recipients had significantly lower SCORAD scores $(27.4 \pm 12.7)$ than prebiotic recipients $(36.3 \pm 14.9 ; p=0.022)[10,24]$. In adults, oral L. salivarius LS01 has been shown to preserve Th1 cytokine production and Th1:Th2 ratios when compared to maltodextrin controls after four months of treatment [25]. L. salivarius' reduction of AD severity via normalization of T-cell function is consistent with the hygiene hypothesis [11].

A Bifidobacterium longum infantis and B. breve combination in fermented infant formula achieved greater IgA responses to the poliovirus vaccine challenge than standard formula [25]. A L. salivarius and B. breve BR03 combination led to improved SCORAD indices in adult AD patients [25]. B. breve Bb99 synbiotic with three additional probiotics given to 459 women during the last two to four weeks of pregnancy and given to their newborns for six months after delivery reduced AD in comparison to 463 controls (Odds Ratio (OR) = 0.74; 95\% CI, 0.55-0.98, $p=0.04$ ) [24]. Similarly, an L. rhamnosus LCS-742 and B. longum infantis M63 synbiotic administered to 39 term newborns for six months reduced AD in comparison with 45 formula-fed control newborns ( $\mathrm{OR}=0.11 ; 95 \% \mathrm{CI}, 0.01-0.94 ; p<0.05)$ [24]. Overall, mixed strain synbiotics appear to be more effective for AD treatment than single strain synbiotics, $p=0.03$, based on a SCORAD-weighted mean difference improvement of 7.32 for 80 treated participants from three studies [24]. Consistent with this, a trial of B. breve M-16V synbiotic versus placebo control in 90 infants less than seven months of age did not find differences in cytokine production or circulating regulator T-cell proportions [26]. However, a mother and infant double-blinded, placebo-controlled trial of LGG, L. rhamnosus LC705, B. breve Bb99, and Propionibacterium freudenreichii spp. Shermanii JS, with 1223 subjects found that in cesarean delivered infants, IgE-associated allergic diseases at five years of age were significantly reduced ( $24.3 \%$ versus $40.5 \%, \mathrm{OR}=0.47 ; 95 \% \mathrm{CI}, 0.23-0.96 \%, p=0.035)$ [27]. It has been postulated that only IgE-associated AD will respond to probiotics [12].

Lysates offer cost-savings over the use of selected single components. Lysates can be included in prepared foods. A randomized controlled trial (RCT) with 41 dry, dark-skinned 25- to 60-year-old patients tested orally consumed $2.1 \%$ L. plantarum K8 (KCTC 10887BP) lysates. The 2.1\% L. plantarum K8 lysates increased forearm skin hydration by the fourth week $(p=0.03)$, but not after eight weeks of use ( $p=0.068)$ [5]. However, facial skin hydration was increased at four weeks $(p=0.00)$ and eight weeks $(p=0.007)$ of use [5]. Orally consumed $2.1 \%$ L. plantarum K8 lysates were associated with significantly decreased horny layer thickness of the forearm and face at four weeks and eight weeks with $p=0.002$ and $p=0.000$ for the face and $p=0.007$ and $p=0.000$ for the forearm [5]. Orally consumed $2.1 \%$ L. plantarum K8 lysates use was associated with statistically significant decreased TEWL of the forearm and face at eight weeks with $p=0.002$ and $p=0.008$, respectively [5]. Therefore, $2.1 \%$ L. plantarum K8 lysates may be regarded as orally consumed skin moisturizers that reduce the need for topical corticosteroids and emollients for AD treatment [5].

Pseudomonas aeruginosa is known for opportunistic infections in burn patients through the use of a toll-like receptor-4 (TLR-4) associated lipopolysaccharide receptor complex to induce an inflammatory and adaptive immune response [20]. L. plantarum, $10^{5} \mathrm{cfu} / \mathrm{mL}$ injected into infected areas on days three, four, five, seven, and nine post infection inhibited P. aeruginosa PA100 colonization of an in vivo burned-murine model, which was measured by the lack of viable P. aeruginosa PA 100 cells, $p<0.001$ [20]. L. plantarum was tried against silver sulphadiazine in 80 patients with delayed, infected second-degree and third-degree burns, or early, non-infected third-degree burns [28]. Within treatment groups of 12 to 15 patients, outcomes lacked statistical power. Nonetheless, when compared to silver sulphadiazine, L. plantarum achieved a $2.72 \%$ lower bacterial load in second-degree burns and $1.07 \%$ less infection in early third-degree burns, but had $16.90 \%$ more infection in delayed, infected third-degree burns [28]. These results were consistent with rabbit models [29]. 
Lactobacillus reuteri ATCC 55730 at $10^{5}$ to $10^{8} \mathrm{cfu} / \mathrm{mL}$ and L. rhamnosus AC413 coinfections increase normal primary human epidermal keratinocytes (NHEK) survival in the presence of concurrent S. aureus infection from $8.8 \%$ in the absence of probiotics to $53.1 \%(p=0.0012)$ and $42.7 \%(p<0.0001)$, respectively [18]. L. reuteri ATCC 55730 lysate also protects NHEK from S. aureus, $p=0.01$. Heat-killed L. reuteri ATCC 55730 is ineffective against S. aureus infection [18]. L. reuteri ATCC 55730 exposure after S. aureus infection is ineffective. L. reuteri ATCC 55730 introduction before or concurrently with S. aureus allows L. reuteri ATCC 55730 to competitively exclude $S$. aureus from NHEK binding sites, $p=0.026$ and $p=0.0078$, respectively [18]. Compared to live L. reuteri ATCC 55730, L. reuteri ATCC 55730 lysates are less effective staphylococcal adhesion inhibitors, $p=0.0002$ versus $p=0.032$ [18]. L. salivarius UCC 118 cannot be substituted for L. reuteri ATCC 55730 since L. salivarius UCC118 adheres less effectively to NHEK than does L. reuteri ATCC 55730, $5.6 \pm 0.1 \log$ cfu versus $6.7 \pm 0.1 \log$ cfu respectively, $p=0.005$ [18].

In vitro studies show that LGG lysates and spent culture fluid can protect human keratinocytes from subsequent $S$. aureus exposure with $p=0.006$ and $p=0.01$ after a 24-h incubation [8]. LGG and LGG lysates were also effective with exposure limited to two hours before or $12 \mathrm{~h}$ after S. aureus infection, $p=0.005$ and $p=0.01$, respectively [8]. Live LGG and LGG lysate physically displace S. aureus from receptors [8]. Live LGG, LGG lysate, and spent culture competitively exclude $S$. aureus from keratinocytes' receptors [8]. Live LGG and LGG lysate inhibited S. aureus growth. However, spent culture did not inhibit $S$. aureus growth [8].

\section{Polyphenols: Flavonoids, Phenolic acids, Stilbenes, and Proanthocyanidins}

Pigmented polyphenols absorb UVR primarily in the UVB spectrum with some UVA and UVC absorption, which facilitates sunscreen function [1]. Globally, Camellia sinensis derived tea is $20 \%$ green tea and is the second most common drink [30,31]. Topical green tea extract is known to reduce UVR-induced p53 expression [1]. Epigallocatechin-3-gallate (EGCG) has been associated with impaired in vitro nucleotide biosynthesis repair via dihydrofolate reductase inhibition [30]. In murine models, topical resveratrol, silymarin, oral resveratrol, silymarin, and grape seed proanthocyanidins inhibit UVB-induced photodamage. This anti-inflammatory action mediates polyphenols' anti-photo-carcinogenesis [1,4].

\subsection{Flavonoids}

Anti-inflammatory, antioxidant, polyphenolic green tea catechins (GTC) inhibit cyclooxygenase-2 and lipoxygenases [6]. Conjugates and metabolites of orally consumed GTC are incorporated into the skin and have been found in skin biopsy specimens [6]. In murine trials, oral GTC and EGCG protected against UVR-induced photodamage and photocarcinogenesis $[1,6]$. EGCG is the primary catechin and the most bioactive constituent of green tea [31,32]. In open, uncontrolled human trials, topical GTC preceding UVR exposure reduced photodamage and oral GTC reduced photodamage by increasing the skin erythema (sunburn) threshold [6]. In controlled human trials, EGCG $\left(<1 \mathrm{mg} / \mathrm{cm}^{2}\right)$ preceding UVR exposure also reduced photodamage [1]. A 34-day, 39-person, controlled trial of topical $4 \%$ green tea extract (OM24) compared to GTC preceding UVB exposure found sunburn reduced by $38.9 \%$ by OM24, $p=0.02$ [33].

Oral GTC metabolites are incorporated into the skin [6]. Oral GTC were studied in a three-month, double-blind, RCT, with 50 female and male 18- to 65-year-old patients, Fitzpatrick skin phototypes I to II representing northern Europeans and Scandinavians [6]. Based on the placebo control, GTC dosed at $1080 \mathrm{mg} / \mathrm{d}$ with vitamin C $100 \mathrm{mg}$ taken daily did not significantly reduce skin erythema, leukocyte infiltration, or eicosanoid response to a UVR inflammatory challenge [6]. The GTC was the equivalent of five cups of green tea daily: comprised of $12.6 \mathrm{mg}$ catechin, $1.8 \mathrm{mg}$ catechin gallate, $75 \mathrm{mg}$ epicatechin, $295.8 \mathrm{mg}$ epigallocatechin, $156 \mathrm{mg}$ epicatechin gallate, $435.6 \mathrm{mg}$ EGCG, $1.8 \mathrm{mg}$ gallic acid, $74.4 \mathrm{mg}$ gallocatechin, and $28 \mathrm{mg}$ gallocatechin gallate. The median interquartile range sunburn threshold (minimal erythema dose) was $20 \mathrm{~mJ} / \mathrm{cm}^{2}$ to $28 \mathrm{~mJ} / \mathrm{cm}^{2}$ in both intervention and 
placebo groups [6]. Post-UVR neutrophil and $\mathrm{CD}^{+}$T-lymphocyte counts were similar in each group, $p$ $=0.85$ and $p=0.62$, respectively [6]. The lack of significant outcomes may be due to under dosing GTC. Men and women who drink more than 10 cups of green tea (equivalent to $2.5 \mathrm{~g}$ of green tea extract) daily have delayed cancer onset by 3.2 years and 7.3 years, respectively [30].

Topical green tea EGCG effects IL-12-dependent DNA repair [30]. However, topical EGCG is subject to photolysis $(76.9 \pm 4.6 \%)$ [32]. $\alpha$-Lipoic acid more effectively reduces photolysis of combined EGCG in comparison with vitamin C (12.6 $\pm 1.6 \%, p<0.05$ versus $20.4 \pm 2.7 \%)$ [32]. $\alpha$-Lipoic acid also most effectively preserves EGCG's antioxidant activity (-1.4\%) [32]. Interestingly, vitamin E increases photolysis of combined EGCG to $84.5 \pm 3.4 \%, p<0.05$ [32].

\subsection{Phenolic Acids}

Dietary phenolic acids are primarily UVA absorbing antioxidants with indirect regulatory effect on the nuclear factor E2-related factor 2-antioxidant responsive element (Nrf2-ARE) pathway [7]. In primary human epidermal melanocytes (HEMn) and B16F10 melanoma cells, Nrf2 inhibits melanogenesis and tyrosinase protein expression. Caffeic acid and ferulic acid are partial UVA protectors. Quercetin and rutin are strong UVA protectors. Avobenzone is an efficient UVA filter lacking antioxidant activity [7]. Normally, B16F10 melanoma cells increase melanin production, tyrosinase activity, and tyrosinase protein expression in response to UVA. B16F10 melanoma cells pretreated with caffeic acid, ferulic acid, quercetin, rutin, and avobenzone display inhibited melanin production and tyrosinase activity. Quercetin is most effective, IC30 7.8 $\pm 1.4 \mu \mathrm{M}$ against melanin production and $10.1 \pm 3.1 \mu \mathrm{M}$ against tyrosinase activity [7]. Rutin, caffeic acid, and avobenzone have equivalent, less effective activity than quercetin, $p<0.05, p<0.01$, and $p<0.001$, respectively. Ferulic acid is least active with IC30 > 30 against melanin production and tyrosinase activity [7]. Nonetheless, quercetin, caffeic acid, and avobenzone may reverse UVA-mediated Nrf2 nuclear translocation downregulation, Nrf2-ARE downregulation, and GCLC, GST, and NQO1 reduction [7]. Although less effective than quercetin, when rutin is added to UVB filters, ethylhexyl methoxycinnamate, ethylhexyl dimethyl PABA, and octocrylene organic UV filters, ROS scavenging is increased by $75 \%(p<0.002)$ and peak wavelength absorption is increased $(p<0.001)$ [34]. Rutin increases the critical wavelength of ethylhexyl dimethyl PABA $(p \leq 0.05)$ [34]. UVA photo-protection of ethylhexyl methoxycinnamate and ethylhexyl dimethyl PABA is increased with the addition of rutin $(p \leq 0.05)$ [34]. Of note, caffeic acid, rutin, and quercetin are found in South African Aspalathus linearis (rooibos) tea. Caffeic acid and ferulic acid are constituents of Polypodium leucotomas, a tropical fern [35]. P. leucotomas extract is commercially available in several products [35]. In a small 9-person study, oral P. leucotomas extract significantly reduced tumorigenesis and immunosuppression associated cyclobutane pyrimidine dimers formed by UVB action on DNA, $p<0.001$ [35]. This finding is consistent with the literature on P. leucotomas [36].

\subsection{Stilbenes and Proanthocyanidins}

Photoprotection and anti-photocarcinogenesis murine trials of resveratrol abound [37]. In vivo murine studies of oral grape seed proanthocyanidins show a dose-dependent anti-photo-carcinogenesis effect [38]. In vivo human trials of oral resveratrol and grape seed proanthocyanidins have been hampered by poor bioavailability [33,37]. Cosmeceutical patents have been awarded based on in vitro human cell line studies [39]. In response, topical delivery mechanisms including hydrogel patches, nano suspensions, co-loaded liposomes, and co-loaded glycerosomes have been developed [37,40]. Nonetheless, topical formulations face bioavailability issues. The active constituents must penetrate and diffuse through the stratum corneum into the stratum basale [16].

Silymarin is up to $80 \%$ silibinin is GRAS [4]. In addition to anti-inflammatory photoprotection, silymarin has antioxidant and immune modulating mechanisms of action. In vivo murine models show topical silibinin and oral grape seed proanthocyanidins have antioxidant properties by inhibiting MAPK ERK and p38 proteins and NF- $\kappa \beta$ activation [4,38]. Topical silibinin inhibits UVR-induced immune suppression by inhibiting leukocyte infiltration especially in MHC + CD $11 \mathrm{~b}+$ cell types [4]. 
In vitro A431 human epidermoid cancer cell line studies show that silibinin induces autophagy by limiting UVB-induced apoptosis [41].

\section{Vitamins $\mathrm{C}$ and $\mathrm{E}$}

Vitamins C and E are normal skin components [42]. UVR-induced erythema is unchanged, but skin and plasma vitamin $C$ content rises with $500 \mathrm{mg}$ daily oral vitamin $C$ supplementation [42]. Up to $10 \%$ topical vitamin $C$ neither irritates nor sensitizes human skin [42]. Vitamin $E$ is currently understood to be comprised of $\alpha-, \beta-, \delta-$, and $\gamma$-tocopherols and $\alpha-, \beta-, \delta-$, and $\gamma$-tocotrienols $[43,44]$. Importantly, tocopherols and tocotrienols have distinct bioactive compartments of distribution $[43,44]$. Although vitamin E inactivation of ROS from UVR exposure is consistent with dose-dependent $\alpha$-tocopherol depletion by UVB with lipophilic penetration in the brain and liver and even intramembrane positioning close to membrane surfaces, tocotrienols are more powerful antioxidants than $\alpha$-tocopherol $[42,43]$. Tocotrienols have anti-inflammatory properties that tocopherols lack [43]. Tocotrienols induce antioxidant enzymes, antigen specific, and antigen nonspecific immune responses [43]. Tocotrienols are cyclooxygenase and 5-lipoxygenase-catalyzed eicosanoids inhibitors, which suppress nuclear factor- $k \beta$, a signal transducer, and activation of transcription (STAT) pro-inflammatory signaling [43]. Therein lies additional biologic basis for vitamin E limiting photo-damage.

Vitamin E comprised 30\% of mixed tocopherols and 70\% of mixed tocotrienols and a water-soluble phenolic-flavonoid-rich antioxidant complex are minor components of Elaies guineensis (West African palm fruit), which was transported globally by the Portuguese in the 15th Century and the Dutch in the 19th Century [45]. Elaeis oleifera (South American palm fruit) has more oleic and linoleic acid and less palmitic and saturated acids than E. guineensis [45]. E. guineensis tocotrienols are unusual since rice bran oil is the only other tocotrienol containing vegetable oil [45]. Palm oil has a higher mixed tocopherol and mixed tocotrienol content $(693.5 \mathrm{mg} / \mathrm{kg})$ than sunflower oil $(547.5 \mathrm{mg} / \mathrm{kg})$ or olive oil $(175.6 \mathrm{mg} / \mathrm{kg})$, but less than rice bran oil $(1198 \mathrm{mg} / \mathrm{kg})$, soybean oil $(902.2 \mathrm{mg} / \mathrm{kg})$, corn oil $(781.4 \mathrm{mg} / \mathrm{kg})$, or wheat germ oil $(702.7 \mathrm{mg} / \mathrm{kg})$ [45]. However, except for rice bran and wheat germ oil, these other oils lack tocotrienols [45]. Tocotrienols have multiple anti-cancer mechanisms of action: malignant cell proliferation and 3-hydroxy-3-methyl-glutaryl-coenzyme A (HMG-CoA) reductase suppression, malignant cell apoptosis induction, cell cycle arrest, immunity enhancement, angiogenesis, and tumor cell migration inhibition [43]. Consistent with this, palm oil vitamin E, which is a water-soluble phenolic-flavonoid-rich antioxidant complex, and carotenoids have demonstrated anti-glioblastoma, anti-neuroblastoma, and an anti-breast, gastric, pancreatic cancer effect in murine models [43,45]. Nano emulsified Malaysian palm oil tocotrienol fraction has been patented with the antioxidant, soy isoflavone, Genistein for slow-release liquid and cream skin photo-protection applications [46]. In vitro, there is a $2.7-\mathrm{h}$ drug release lag time [46]. Cell viability following UVB-exposure reached $80 \%$, $p<0.03$, when compared to control cells [46].

\section{Other Supplements-Carotenoids, Coenzyme Q10, Polyunsaturated Fatty Acids}

Based on 20 healthy adults, an oral combination of $25 \mathrm{mg}$ total carotenoids and $335 \mathrm{mg}$ (500 International Units) $R R R$ - $\alpha$-tocopherol daily for 12-weeks reduced dorsal skin erythema $(p<0.01)$ by week nine in comparison to $25 \mathrm{mg}$ total carotenoids daily [47]. Combinations of $\beta$-carotene, lycopene (a lipophilic carotenoid), and lutein can provide equivalent photoprotection to higher doses of $\beta$-carotene used alone [48]. This is important for smokers and those exposed to asbestos who must limit $\beta$-carotene intake [48]. A commercially available combination of lycopene $2.5 \mathrm{mg}$, $\beta$-carotene, and Lactobacillus johnsonii $5.10 \times 10^{8} \mathrm{cfu}$ was the intervention in a 12-week randomized, double-blinded, placebo-controlled trial with 60 patients who had polymorphic light eruptions [49]. The combination of lycopene $2.5 \mathrm{mg}, \beta$-carotene, and L. johnsonii $5.10 \times 10^{8} \mathrm{cfu}$ was able to reduce the effect of a single exposure to longwave UV radiation (UVA1), $p<0.001$, but that of multiple exposures [49]. UVA1-inducible gene mRNA expression is a surrogate marker for UVA exposure [48,49]. Intracellular adhesion molecule-1 mRNA levels are associated with polymorphic light eruptions 
following UVA1 exposure, $p<0.001$, and $p=0.022$ in the placebo group [49]. Lycopene $16 \mathrm{mg}$ from tomato paste $55 \mathrm{~g}$ in olive oil or olive oil only were consumed daily by 20 women with FitzPatrick skin phototypes I or II in a 12-week, RCT [50]. Tomato paste increased the mean erythemal dose by 30 units $(p=0.03)$, increased procollagen deposition $(p=0.05)$, reduced UVR-induced matrix metalloproteinase-1 $(p=0.04)$, and reduced mitochondrial DNA 3895-base pair deletion after $3 \times$ minimal erythema dose UV exposure $(p=0.01)$ [50]. Olive oil carrier was used for increased lycopene absorption [50]. A $5 \mathrm{mg}$ lycopene with tomato phytonutrient complex including tocopherols and phytosterols soft gel capsule (TNC) or $10 \mathrm{mg}$ free lutein were stabilized with $10 \%$ carnosic acid soft gel capsule (LCC) dosed as 2-TNC twice daily or 1-LCC twice daily, which were trialed against a soybean oil soft gel capsule placebo [48]. Based on 65 participants in a 28-week long, double-blind, randomized, crossover trial, when TNC or LCC were received from day 1 , there is similar UVA, UVB, and longwave UVA1 protection [48]. The doses of TNC and LCC used correspond to $130 \mathrm{~g}$ of chopped kale and $242 \mathrm{~g}$ of tomato juice [48].

The antioxidant, coenzyme Q10 is essential for mitochondrial energy metabolism [51]. In contrast to the literature of in vitro studies, a 33-person double-blind, placebo-controlled study of $50 \mathrm{mg}$ and $150 \mathrm{mg}$ of oral coenzyme Q10 daily for 12-weeks did not find a significant increase in the minimal erythema dose (MED). At 12 weeks, the placebo MED was $0.62 \mathrm{~J} / \mathrm{cm}^{2} \pm 0.04,50 \mathrm{mg}$ coenzyme Q10 MED was $0.72 \mathrm{~J} / \mathrm{cm}^{2} \pm 0.06$ and $150 \mathrm{mg}$ coenzyme Q10 MED was $0.70 \mathrm{~J} / \mathrm{cm}^{2} \pm 0.06, p=0.49$ [51].

A 3-month, 42-person, double-blind randomized trial of omega-3 polyunsaturated fatty acids $4 \mathrm{~g}$ daily, eicosapentaenoic acid (EPA), or monounsaturated oleic acid found that EPA was the most promising for photo-protection [52]. EPA increased the UV-induced erythemal threshold by $13 \mathrm{~mJ} / \mathrm{cm}^{2}$, $p<0.01$, and reduced p53 UV-induced skin expression by 50\%, $p<0.01$ [52]. This was a follow-up to a successful trial of $10 \mathrm{~g}$ fish oil daily for three months or six months in which the MED was more than doubled [53].

\section{Discussion}

The preceding sections and the synopsis of selected references in Table 1 show a broad array of skin protective nutraceuticals. For different pathologic processes, a given nutraceutical can be effective through different mechanisms of action, as indicated in Table 2. Multiple mechanisms of action allow probiotics to be effective for immunologic-based $\mathrm{AD}$, prevent skin dehydration and infections, and promote wound healing $[5,8,9,12,18,27]$. Given an expanding body of evidence, over time, recommendations supporting maternal oral probiotic consumption during pregnancy and lactation have gained strength $[12,13,23,27]$. A person's microbiota is partially determined by delivery route [27]. Oral maternal combination probiotics are a means to give persons delivered by cesarean a similar microbiome as those delivered vaginally. L. salivarius symbiotic should be considered for AD treatment given reduced AD severity measured by SCORAD, $p=0.022$ [10]. Probiotic formulation affects efficacy. B. breve may need additional trials as a combination probiotic in fermented foods before significant effects on AD was seen [25]. The combination probiotic LGG, L. rhamnosus LC705, B. breve Bb99, and Propionibacterium freudenreichii spp. Shermanii JS, reduced IgE-associated allergic diseases in cesarean-delivered infants $(p=0.035)$, but $B$. breve as a single administered probiotic did not affect cytokine production or circulating regulator T-cell proportion [26,27]. Successful probiotic use in IgE-associated AD stimulates toll-like receptors by modulating cytokines and inducing IgA [27]. Future probiotic trials for $\mathrm{AD}$ need subgroup analysis for IgE-associated $\mathrm{AD}$ and for birth by cesarean delivery $[12,27]$. 
Table 1. Selected reference synopsis.

\begin{tabular}{|c|c|c|}
\hline \multicolumn{3}{|c|}{ Skin, Photodamage, Photoprotection, Anti-Photocarginogenesis, and Atopic Dermatitis } \\
\hline Ref. & Type & Primary Results \\
\hline$[1]$ & Review & $\begin{array}{l}\text { Describes the effects of different solar ultraviolet radiation spectra on the skin, } \\
\text { which leads to photocarginogenesis. }\end{array}$ \\
\hline [5] & Experimental & $\begin{array}{l}\text { Describes skin function and the physiologic basis of atopic dermatitis. } \\
\text { Suggests probiotics positively affect lipoteichoic acid a cell wall component. }\end{array}$ \\
\hline [8] & Experimental & $\begin{array}{l}\text { One-chapter description of skin structure and barrier function, wound formation } \\
\text { and immunologic response, and probiotics' roles in human health. }\end{array}$ \\
\hline \multicolumn{3}{|r|}{ Probiotics } \\
\hline Ref. & Type & Primary Results \\
\hline [11] & Review & $\begin{array}{l}\text { Hygiene hypothesis originated from the inverse correlation between hay fever } \\
\text { and the number of older siblings in British children. Extended to autoimmune } \\
\text { disorders: infections against the basis of epidemiological data, animal models, } \\
\text { and human intervention trials. Infections are protective against many immune- } \\
\text { related disorders. Lack of infections } \uparrow \mathrm{T} \text { helper type } 1, \downarrow \text { T helper type } 2 \text { cells, } \\
\text { favors strong immune responses from weak antigens, and is consistent with } \\
\text { increasing incidence of atopic dermatitis, asthma, and allergic rhinitis. } \\
\text { Probiotics and microbiota are weak antigens and non-antigenic ligands that alter } \\
\text { immuno-regulatory mechanisms. Probiotics and microbiota modulate } \\
\text { immune responses. }\end{array}$ \\
\hline [12] & Review & $\begin{array}{l}\text { Reviews atopic dermatitis epidemiology and pathophysiology, hygiene } \\
\text { hypothesis, intestinal microbiome, probiotics, prebiotics, and synbiotics. }\end{array}$ \\
\hline [30] & Review & $\begin{array}{l}\text { Epidemiology and cost of nonmelanoma skin cancer in the United States of } \\
\text { America. Reviews ultraviolet radiation's photo-damaging effects and topical } \\
\text { sunscreens' limitations. }\end{array}$ \\
\hline [5] & Experimental & $\begin{array}{l}\text { Describes relationship betweeen probiotics, gastrointestinal microbiota, and } \\
\text { atopic dermatitis incidence. Randomized controlled trial of orally consumed } \\
\text { Lactobacillus plantarum K8 (KCTC 10887BP) } 2.1 \% \text { lysates, with 6-weeks old SKH-1 } \\
\text { hairless mice and } 41 \text {-participants aged } 25 \text { to } 60 \text { years old. In vivo, hydration } \uparrow \text { in } \\
\text { the intervention group on the face after four and eight weeks }(p=0.000, p=0.007 \text {, } \\
\text { respectively). Horny layer thickness } \downarrow \text { at four weeks and eight weeks for the face } \\
(p=0.002, p=0.000) \text { and the forearm }(p=0.007 \text { and } p=0.000) \text {. Transepidermal } \\
\text { water loss } \downarrow \text { on the face and forearm at eight weeks }(p=0.008, p=0.002 \text {, } \\
\text { respectively). Orally consumed L. plantarum K8 lysates improved skin } \\
\text { barrier function. }\end{array}$ \\
\hline [8] & Experimental & $\begin{array}{l}\text { Doctoral thesis. In vitro effect of probiotics on Staphylococcus aureus infected } \\
\text { wounds. Live Lactobacillus rhamnosus GG } \uparrow \text { infected human keratinocytes' } \\
\text { viability from } 25 \text { to } 57 \% \text { at } 24 \text {-h of incubation. L. rhamnosus GG lysates and spent } \\
\text { culture fluid also protected keratinocytes ( } p=0.006, p=0.01 \text { ). }\end{array}$ \\
\hline [9] & Review & $\begin{array}{l}\text { Twelve case-control studies from Australia and Europe. Brief decription of atopic } \\
\text { dermatitis and Scoring Atopic Dermatitis (SCORAD) evaluation system. } \\
\text { Nine studies found probiotics to be beneficial in atopic dermatitis by providing } \\
\text { infection prevention, improved immunologic response with a bifidobacteria } \\
\text { altered gut microbiome, and reduced inflammation. Outcomes: Oral } \\
\text { Lactobacillus rhamnosus GG use reduces SCORAD ( } p=0.02 \text { ). Four weeks of oral } \\
\text { L. rhamnosus GG reduced intestinal inflammation in children with atopic } \\
\text { dermatitis and allergy to cow's milk. In a population in which } 71 \% \text { had high IgE } \\
\text { food antigen responses, oral L. fermentum VRI-003 reduced moderate and severe } \\
\text { atopic dermatitis (SCORAD improvement } p=0.03 \text { ). }\end{array}$ \\
\hline [10] & Review & $\begin{array}{l}\text { Probiotics given to young infants may prevent atopic dermatitis development. } \\
\text { Prebiotic-controlled trial of L. salivarius in } 60 \text { children, } 2 \text {-years-old to } 14 \text {-years-old, } \\
\text { found improved atopic dermatitis at } 8 \text {-weeks and 10-weeks (SCORAD } \\
\text { improvement } p=0.022 \text { ). Placebo-controlled trial of L. plantarum CJLP133 in } \\
118 \text { children, } 1 \text {-years-old to } 13 \text {-years-old, found improved atopic dermatitis at } \\
14 \text {-weeks (SCORAD improvement } p=0.044 \text { ). }\end{array}$ \\
\hline
\end{tabular}


Table 1. Cont.

\begin{tabular}{|c|c|c|}
\hline$[24]$ & Meta-analysis & $\begin{array}{l}\text { Six treatment studies ( } 369 \text { children, } 0 \text {-years-old to } 14 \text {-years-old) and two } \\
\text { prevention studies ( } 1320 \text { children, } 0 \text {-months-old to } 6 \text {-months-old) of synbiotic } \\
\text { use in atopic dermatitis. The treatment studies were heterogenic }\left(\mathrm{I}^{2}=77.1 \% \text {, }\right. \\
p=0.001) \text {. Mixed strain synbiotics were beneficial }(p=0.03) \text {. Synbiotics were } \\
\text { beneficial for children at least } 1 \text {-year-old }(p=0.048) \text {. Synbiotics were not shown } \\
\text { to prevent atopic dermatitis }(p=0.26) \text {. }\end{array}$ \\
\hline$[25]$ & Review & $\begin{array}{l}\text { Intestinal microbiota composition associated with atopic dermatitis: Neonates } \\
\text { who develop atopy have different microbiota to neonates who do not develop } \\
\text { atopy. Probiotics affect T-regulatory and T-helper cells, augment IgA responses, } \\
\text { and evolve adaptive T-cell immunity. }\end{array}$ \\
\hline \multicolumn{3}{|r|}{ Probiotics } \\
\hline Ref. & Type & Primary Results \\
\hline [27] & Experimental & $\begin{array}{l}\text { Double-blind, placebo-controlled study of combined strain probiotic } \\
\text { ( } 2 \text { lactobacilli, } 1 \text { bifidobacteria, and } 1 \text { propionibacteria) with } 1223 \text { mothers with } \\
\text { infants from the last month of pregnancy through six-month-old infants. } \\
\text { Five-year visit data outcomes analysis: probiotic receiving cesarean-delivered } \\
\text { children had less IgE-associated allergic diseases }(24.3 \% \text { versus } 40.5 \% \text {; } \\
\text { odds ratio } 0.47 ; 95 \% \text { confidence interval, } 0.23 \text { to } 0.96 \%, p=0.035) \text {. }\end{array}$ \\
\hline$[28]$ & Experimental & $\begin{array}{l}\text { Eighty burn patients treated with L. plantarum or silver sulphadiazine. } \\
\text { L. plantarum competes with pathogenic bacteria, alters the wound } \\
\text { microenviroment, and promotes tissue repair. Demonstrated the equivalence } \\
\text { of L. plantarum to silver sulphadiazine. }\end{array}$ \\
\hline \multicolumn{3}{|r|}{ Polyphenols } \\
\hline Ref. & Type & Primary Results \\
\hline [16] & Review & $\begin{array}{l}\text { Chemical classification, physicochemical properties, transportation through the } \\
\text { skin, metabolism, and physiological mechanisms of action (anti-inflammation, } \\
\text { estrogen-like, anti-infective, and anti-aging). }\end{array}$ \\
\hline \multicolumn{3}{|r|}{ Flavonoids } \\
\hline Ref. & Type & Primary Results \\
\hline [1] & Review & $\begin{array}{l}\text { Mechanisms of selected polyphenols' photo-protective and } \\
\text { anti-photo-carcinogenic effects: green tea polyphenols, grape seed } \\
\text { proanthocyanidins, resveratrol, silymarin, and genistein. Primarily } \\
\text { anti-inflammatory and antioxidant. Plasma bioavilability limited by conjugation } \\
\text { to glucuronide, sulphate, and methyl groups. As water additives, green tea } \\
\text { polyphenols protect against skin tumorigenesis in murine models. Topically } \\
\text { photo-protective in human models, it reduces erythema, inflammation, } \\
\text { and tissue infiltration. Topical and oral epigallocatechin-3-gallate are } \\
\text { photo-protective. }\end{array}$ \\
\hline [6] & Experimental & $\begin{array}{l}\text { 50-participant, double-blind, randomized, placebo-controlled trial of } 1350 \mathrm{mg} \\
\text { green tea catechins and } 50 \mathrm{mg} \text { vitamin C twice daily for three months, } \\
\text { clinicaltrials.gov registration number NCT01032031. Minimal erythemal dose } \\
\text { was not significantly different across groups. Similar skin neutrophil, CD3 } \\
\text { T-lymphocytes, cyclooxygenase, and lipoxygenase metabolites prostaglandin E2, } \\
\text { and 12-hydroxyeicosatetraenocacid across groups. }\end{array}$ \\
\hline$[30]$ & Review & $\begin{array}{l}\text { Classification of polyphenol constistuents of green tea. Green tea polyphenol use, } \\
\text { limitations, biologic plausibility, mechanisms of action, and potential } \\
\text { photoprotection and anti-photo-carinogenesis role. }\end{array}$ \\
\hline$[31]$ & Review & $\begin{array}{l}\text { Mechanism of action based on medicinal application of green tea's constituents } \\
\text { for photoprotection, dermatologic, and infectious disease treatment. }\end{array}$ \\
\hline$[32]$ & Experimental & $\begin{array}{l}\text { In vitro photo-degradation studies of } 1 \% \text { epigallocatechin-3-gallate emulsions } \\
\text { with and without equimolar co-oxidants } \alpha \text {-lipoic acid, butylated hydroxytoulene, } \\
\text { vitamin } C \text {, and vitamin E. Vitamins } C \text { and } \alpha \text {-lipoic acid reduced photodegration } \\
\text { of epigallocatechin-3-gallate from } 76.9 \pm 4.6 \% \text { to } 20.4 \pm 2.7 \% \text { and } 12.6 \pm 1.6 \% \text {, } \\
\text { respectively while vitamin E increased photodegration to } 84.5 \pm 3.4 \% \text {. } \\
\text { An antioxidant activity decrease was at the lowest value with } \alpha \text {-lipoic acid, } 1.4 \% \text {, } \\
\text { making } \alpha \text {-lipoic acid the best of the four trialed co-oxidants to stabilize } 1 \% \\
\text { epigallocatechin-3-gallate emulsions. }\end{array}$ \\
\hline
\end{tabular}


Table 1. Cont

\begin{tabular}{|c|c|c|}
\hline \multicolumn{3}{|r|}{ Flavonoids } \\
\hline Ref. & Type & Primary Results \\
\hline [33] & Review & $\begin{array}{l}\text { Seven human subjects and eight murine studies encompass polyphenols from } \\
\text { Calluna vulgaris, cocoa, green or white tea, grape seeds, honeybush, } \\
\text { Lepidium meyenii (maca), and Romanian propolis. Efficacy, the mechanism of } \\
\text { action, and adverse effects of various polyphenol formulations need } \\
\text { further study. }\end{array}$ \\
\hline \multicolumn{3}{|r|}{ Phenolic Acids } \\
\hline Ref. & Type & Primary Results \\
\hline [7] & Experimental & $\begin{array}{l}\text { In vitro, primary human epidermal melanocyte and B16F10 melanoma cell trial } \\
\text { of caffeic acid, ferulic acid, quercetin, rutin, and avobenzone. All five phenolics } \\
\text { showed anti-melanogenic effects in reversal of ultraviolet-A radiation-mediated } \\
\text { oxidative damage and downregulation of Nuclear factor E2-related factor } 2 \\
\text { activity in B16F10 cells. This section discusses oxidative stress mechanisms. }\end{array}$ \\
\hline [34] & Experimental & $\begin{array}{l}\text { In vitro synergism of rutin with ultraviolet filters (ethylhexyl methoxycinnamate } \\
\text { and ethylhexyl dimethyl para-aminobenzoic acid) from reactive oxygen species } \\
\text { scavenging (also synergistic with octocrylene), prevents sunscreen photolysis } \\
\text { and increases ultraviolet-A critical wavelengths with photoprotective gain } \\
(p \leq 0.05) \text {. }\end{array}$ \\
\hline [35] & Review & $\begin{array}{l}\text { Caffeic acid and ferulic acid containing Polyodium leucotomos is photoprotective } \\
\text { and anti-photocarcinogenic via anti-inflammatory, antioxidant, antitumorigenic, } \\
\text { and immunoregulatory mechanisms. Oral P. leucotomos is a potential systemic } \\
\text { photoprotective and anti-photocarcinogenic agent. }\end{array}$ \\
\hline [36] & $\begin{array}{l}\text { Systematic } \\
\text { review }\end{array}$ & $\begin{array}{l}\text { Four studies suggest that } P \text {. leucotomos is photoprotective. Three studies found } \\
\text { that } P \text {. leucotomos delayed or prevented polymorphous light eruptions or solar } \\
\text { urticaria. One study found a trend toward reduced ultraviolet radiation induced } \\
\text { DNA mutations following exposure to two or three times the minimal erythemal } \\
\text { dose ( } p=0.06 \text { and } p=0.07 \text {, respectively). }\end{array}$ \\
\hline \multicolumn{3}{|r|}{ Stilbenes } \\
\hline Ref. & Type & Primary Results \\
\hline [1] & Review & $\begin{array}{l}\text { Topical and oral silymarin and silibinin are anti-photocarcinogenic in murine } \\
\text { models. }\end{array}$ \\
\hline [41] & Experimental & $\begin{array}{l}\text { In vitro study showed that silibinin-induced autophagy photoprotects human } \\
\text { epidermoid carcinoma A431 cells from ultraviolet-B radiation, which induced } \\
\text { apoptosis via the insulin growth factor-1 Receptor-Protein kinase B (IGF-1R-Akt) } \\
\text { pathway activation. Rapamycin is an autophagy inducer enchanced } \\
\text { silibinin's effects. }\end{array}$ \\
\hline \multicolumn{3}{|r|}{ Proanthocyanidins } \\
\hline Ref. & Type & Primary Results \\
\hline$[1]$ & Review & $\begin{array}{l}\text { Grape seeds as dietary additives protect from skin tumorigenesis in murine } \\
\text { models. Polymeric with limited gastrointestinal absorption. }\end{array}$ \\
\hline \multicolumn{3}{|r|}{ Proanthocyanidins } \\
\hline Ref. & Type & Primary Results \\
\hline [38] & Review & $\begin{array}{l}\text { Vitis vinifera (Grape) seeds proanthocyanidins are the main red wine polyphenol. } \\
\text { These are more effective antioxidants and reactive oxygen species scavengers } \\
\text { than vitamins } C \text { and E. For anti-photocarcinogenesis use, mitogen-activated } \\
\text { protein kinases and nuclear factor- } \mathrm{k} B \text { signaling pathways and } \\
\text { immunosuppression through alterations in immunoregulatory cytokines. } \\
\text { In vitro and in vivo murine studies suggest that dietary grape seed } \\
\text { proanthocyanidins should undergo human trials. }\end{array}$ \\
\hline$[40]$ & Experimental & $\begin{array}{l}\text { In vitro study of resveratrol and gallic acid co-loaded in phospholipid vesicles } \\
\text { dispersed in water-propylene glycol or water-glycerol liposomes. Gallic acid } \\
\text { accumulated in the skin, keratinocytes, and fibrobasts were protected from } \\
\text { oxidative damage and antimicrobial activity was shown. }\end{array}$ \\
\hline
\end{tabular}


Table 1. Cont.

\begin{tabular}{|c|c|c|}
\hline \multicolumn{3}{|r|}{ Vitamins $\mathrm{C}$ and $\mathrm{E}$} \\
\hline Ref. & Type & Primary Results \\
\hline [32] & Experimental & $\begin{array}{l}\text { In vitro photodegradation studies of } 1 \% \text { epigallocatechin-3-gallate emulsions } \\
\text { with and without equimolar co-oxidants } \alpha \text {-lipoic acid, butylated hydroxytoulene, } \\
\text { vitamin } C \text {, and vitamin E. Vitamins } C \text { and } \alpha \text {-lipoic acid reduced photodegration } \\
\text { of pigallocatechin-3-gallate from } 76.9 \pm 4.6 \% \text { to } 20.4 \pm 2.7 \% \text { and } 12.6 \pm 1.6 \% \text {, } \\
\text { respectively. Antioxidant activity decreased the least with } \alpha \text {-lipoic acid, } 1.4 \% \text {. }\end{array}$ \\
\hline \multicolumn{3}{|r|}{ Vitamins $C$ and $E$} \\
\hline Ref. & Type & Primary Results \\
\hline [42] & Review & $\begin{array}{l}\text { Describes ultraviolet radiation's effect on the skin and the skin's antioxidant } \\
\text { defenses: } \beta \text {-carotene, Coenzyme Q10, glutathione, green tea, retinoids, } \\
\text { Vitamin C, and Vitamin E. }\end{array}$ \\
\hline$[43]$ & Review & $\begin{array}{l}\text { Describes the differences between tocotrienols and tocopherols by focusing on } \\
\text { tocotrienols action against chronic diseases in contrast to } \alpha \text {-tocopherol's. Reactive } \\
\text { nitrogen species scavenging, cyclooxygenase- and 5-lipoxygenase-catalyzed } \\
\text { eicosanoids inhibition, and proinflammatory signalling suppression: nuclear } \\
\text { factor- } k B \text { and signal transducer and activation of transcription (STAT) action. } \\
\text { Tocotrienols' pharmacology, metabolism, toxicology, and biosafety are discussed. }\end{array}$ \\
\hline$[44]$ & Review & $\begin{array}{l}\text { Focus on cardioprotection. Reviews sources of toctrienols, bioavailability, } \\
\text { and antioxidant effects. }\end{array}$ \\
\hline$[45]$ & Review & $\begin{array}{l}\text { Palm fruit chemistry: tocotrienol, carotenoid-rich, saturated and } \\
\text { monounsaturated fatty acids, antioxidant and anti-cancer effects including those } \\
\text { of a water-soluble phenolic-flavonoid-rich complex. }\end{array}$ \\
\hline \multicolumn{3}{|r|}{ Carotenoids } \\
\hline Ref. & Type & Primary Results \\
\hline [47] & Experimental & $\begin{array}{l}\text { 12-week, dual intervention, randomized, self-controlled study with } \\
20 \text { participants, } 20 \text {-years old to } 57 \text {-years old, Fitzpatrick skin phototypes I or II. } \\
\text { Dunaliella salina derived } 20 \% \text { carotenoid mixture (primarily } \beta \text {-carotene) in } \\
\text { soybean oil with } 3 \% \text { to } 5 \% \text { algal sterols and hydrocarbons dosed at } 25 \mathrm{mg} \\
\text { carotenoids daily and } 25 \mathrm{mg} \text { carotenoids with } 335 \mathrm{mg} R R R \text { - } \alpha \text {-tocopherol daily } \\
\text { formed the interventions. }\end{array}$ \\
\hline [47] & $\begin{array}{l}\text { Experimental } \\
\text { (continued) }\end{array}$ & $\begin{array}{l}\text { The carotenoid and } R R R-\alpha \text {-tocopherol intervention achieved greater eythema } \\
\text { suppression than carotenoid only intervention. Both groups had yellowing of the } \\
\text { skin primarily of the palms and face. }\end{array}$ \\
\hline [49] & Experimental & $\begin{array}{l}\text { Randomized, placebo-controlled, double-blinded study with } 60 \text { adult } \\
\text { polymorphic light eruption patients, Fitzpatrick skin phototypes I, II, or III, } \\
\text { non-obese, and }<125 \mathrm{~g} / \text { day fermented food intake. Lycopene } 2.5 \mathrm{mg} \text {, } \beta \text {-carotene } \\
4.7 \mathrm{mg} \text {, and Lactobacillus johnsonii } 5 \times 10^{8} \mathrm{cfu} \text {, nutritional supplement reduced } \\
\text { polymorphic light eruption score after a single ultraviolet-A1 exposure }(p<0.001) \\
\text { but not after two exposures. The intervention increased intracellular adhesion } \\
\text { molecule } 1 \text { mRNA expression }(p=0.022) \text {. }\end{array}$ \\
\hline$[50]$ & Experimental & $\begin{array}{l}\text { Randomized, olive-oil controlled study with } 20 \text { women, } 21 \text {-years-old to } \\
47 \text {-years-old, Fitzpatrick skin phototypes I or II. Lycopene } 16 \text { mg in } 55 \text { g tomato } \\
\text { paste in olive oil was consumed daily for } 12 \text { weeks. The intervention increased } \\
\text { the mean erythemal D30 ( } p=0.03) \text {, reduced matrix metalloproteinase- } 1 \text { ( } p=0.04) \text {, } \\
\text { and reduced mitochondrial DNA 3895-basepair deletion }(p=0.01) \text {. }\end{array}$ \\
\hline
\end{tabular}


Table 1. Cont.

\begin{tabular}{|c|c|c|}
\hline \multicolumn{3}{|r|}{ Coenzyme Q10 } \\
\hline Ref. & Type & Primary Results \\
\hline [51] & Experimental & $\begin{array}{l}\text { Dual intervention, randomized, placebo-controlled study with } 33 \text { women, } 45 \text { - to } \\
\text { 60-years-old, Fitzpatrick skin phototypes II or II. The low-dose intervention was } \\
\text { coenzyme Q10 } 50 \mathrm{mg} \text { /day and the high-dose intervention was coenzyme Q10 } \\
150 \mathrm{mg} / \text { day. Both low-dose and high-dose coenzyme Q10 showed skin } \\
\text { viscoelasticity and hydration retention while the placebo did not }(p=0.03 \text { and } \\
p=0.06 \text {, respectively). High-dose coenzyme Q10 was protective against } \\
\text { periorbital and upper radial lip line wrinkles }(p<0.05) \text { and nasolabial fold and } \\
\text { corner of the mouth wrinkles }(p<0.01) \text {. Low-dose coenzyme Q10 was protective } \\
\text { against periorbital line wrinkles }(p<0.05) \text {. }\end{array}$ \\
\hline \multicolumn{3}{|r|}{ Polyunsaturated Fatty Acids } \\
\hline Ref. & Type & Primary Results \\
\hline$[52]$ & Experimental & $\begin{array}{l}\text { Dual intervention, double-blind, randomized study, } 42 \text {-subjects, } 21 \text { - to } \\
\text { 65-years-old, Fitzpatrick skin phototypes II or III. The } 3 \text {-month long oral } \\
\text { interventions were the } \omega \text {-3-fatty acid eicosapentaenoic acid } 4 \mathrm{~g} / \text { day or oleic acid } \\
4 \mathrm{~g} / \text { day. Eicosapentaenoic acid increased the erythemal threshold }(p<0.01) \text { and } \\
\text { reduced ultraviolet radiation induced p53 exression }(p<0.01) \text {. }\end{array}$ \\
\hline [53] & Review & $\begin{array}{l}\text { The anti-inflammatory mechanism of action of } n \text {-3-polyunsaturated fatty acids } \\
\text { reduced prostaglandin and cytokine production in response to } \\
\text { ultraviolet radiation. }\end{array}$ \\
\hline
\end{tabular}

$\overline{\mathrm{CD} 3+}$, cluster of differentiation three activating T-cell co-receptor; IgE, immunoglobulin E; IGF-1R-Akt, insulin growth factor-1 Receptor-Protein kinase B; Ref., references; SCORAD, scoring atopic dermatitis evaluation system; STAT, signal transducer and activation of transcription. 
Table 2. Skin protective nutraceuticals' mechanisms of action.

\begin{tabular}{|c|c|c|c|c|c|c|c|c|c|}
\hline $\begin{array}{l}\text { Skin Damage Form: } \\
\text { Mechanism/Effect }\end{array}$ & Probiotics & $\begin{array}{l}\begin{array}{l}\text { Flavonoids } \\
\text { Quercetin }\end{array} \\
\end{array}$ & $\begin{array}{c}\text { Phenolic Acids } \\
\text { Caffeic, Ferulic, \& } \\
\text { Gallic Acids, Rutin }\end{array}$ & $\begin{array}{c}\text { Stilbenes } \\
\text { Resveratrol } \\
\text { Silibinin (Silymarin) }\end{array}$ & $\begin{array}{c}\text { Vitamin E } \\
\text { Tocotrienols }\end{array}$ & $\begin{array}{c}\text { Carotenoids } \\
\text { Tomato Derived }\end{array}$ & Coenzyme Q10 & $\begin{array}{l}\text { Eicosa-Pentaenoic } \\
\text { Acid (EPA) }\end{array}$ & $\begin{array}{c}\text { Green Tea } \\
\text { Epigallocatechin-3-gallate }\end{array}$ \\
\hline \multicolumn{5}{|c|}{ Ultraviolet Radiation (UVR) } & \multicolumn{5}{|c|}{ Ultraviolet Radiation (UVR) } \\
\hline $\begin{array}{c}\text { Photodamage: } \\
\text { Impaired extracellular } \\
\text { matrix }\end{array}$ & - & - & - & $\begin{array}{l}\text { Protects collagen from } \\
\text { UVR-induced } \\
\text { degradation [37]. }\end{array}$ & $\begin{array}{c}\uparrow \text { Collagen synthesis } \\
{[47] .}\end{array}$ & $\begin{array}{c}\downarrow \text { UVR-induced } \\
\text { fibrillin-1 reduction } \\
\text { [50]. }\end{array}$ & $\begin{array}{c}\text { 个dermal and epidermal } \\
\text { basement membrane } \\
\text { components } \\
\text { Maintains viscoelasticity [51]. }\end{array}$ & - & $\downarrow$ UVR-induced collagenase [1]. \\
\hline $\begin{array}{l}\text { Photodamage: Minimal } \\
\text { erythemal dose (MED) }\end{array}$ & - & - & - & $\uparrow \operatorname{MED}[33]$. & - & Unclear [36,42]. & - & $\uparrow$ MED [52]. & Conflicting $\uparrow \operatorname{MED}[1,6,32,33]$. \\
\hline $\begin{array}{l}\text { Photodamage: } \\
\text { UVR-induced } \\
\text { inflammation }\end{array}$ & $\downarrow$ Immune responses & $\begin{array}{c}\text { Anti-inflammatory } \\
{[14,16] .}\end{array}$ & 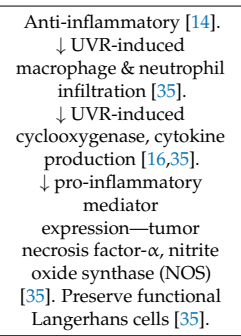 & $\begin{array}{c}\text { Anti-inflammatory } \\
{[4,14,16] \cdot \downarrow \text { leukocyte }} \\
\text { infiltration, edema, } \\
\text { prostaglandindi } \\
\text { metabolites, and } \\
\text { cyclooxygenase-2, }[4,37] . \\
\downarrow \text { pro-inflammatory } \\
\text { mediator } \\
\text { expression-NOS } \\
\text { exp]. }\end{array}$ & $\begin{array}{c}\text { Anti-inflammatory } \\
{[43,44,47] \text {. }}\end{array}$ & $\begin{array}{l}\uparrow \text { intercellularadhesion } \\
\text { molecule-1 mRNA } \\
\text { expression [49]. }\end{array}$ & - & $\begin{array}{l}\downarrow \text { UVR-induced } \\
\text { prostaglandins \& } \\
\text { cytokines [53]. }\end{array}$ & 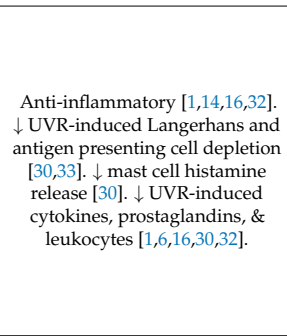 \\
\hline $\begin{array}{l}\text { Photodamage: } \\
\text { Altered immune- } \\
\text { regulation }\end{array}$ & - & - & $\begin{array}{l}\text { Prevent trans-urocanic } \\
\text { acid photoisomerization } \\
\text { \& photodecomposition } \\
\text { [35]. }\end{array}$ & $\begin{array}{l}\downarrow \text { UVR-induced immune } \\
\text { suppression [4]. }\end{array}$ & 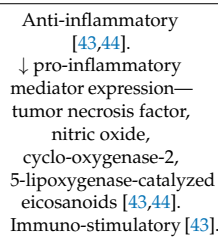 & d]. & - & - & $\begin{array}{l}\text { Dose-dependent } \downarrow \text { UVR-induced } \\
\text { immune-suppression [30]. } \\
\text { Possible dose and / /or gender } \\
\text { based } \downarrow \text { pro-inflammatory } \\
\text { mediator expression-nitric } \\
\text { oxide, hydrogen peroxide, } \\
\text { cyclo-oxygenase-2 [6]. }\end{array}$ \\
\hline $\begin{array}{l}\text { Photodamage: } \\
\text { Reactive oxygen } \\
\text { species (ROS) } \\
\text { generation }\end{array}$ & - & Antioxidative [14]. & 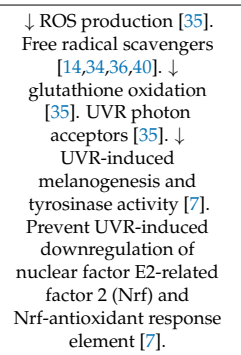 & $\begin{array}{c}\text { Antioxidative }[4,14,37] . \\
\downarrow \text { UVR-induced } \\
\text { intracellular peroxide } \\
\text { and nitric oxide }[4] .\end{array}$ & $\begin{array}{l}\text { Antioxidative } \\
{[32,44,45] .} \\
\downarrow \text { NOS and lipid } \\
\text { peroxidation [43,44]. } \\
\text { Scavenges ROS and } \\
\text { nitrogen-based free } \\
\text { radicals }[43,46] .\end{array}$ & $\begin{array}{l}\text { Antioxidative [42]. } \\
\text { ROS scavenging [47]. }\end{array}$ & $\begin{array}{l}\downarrow \text { UVR-induced ROS } \\
\text { production [42]. }\end{array}$ & $\begin{array}{c}\text { ROS } \\
\text { scavenging [53]. }\end{array}$ & $\begin{array}{c}\text { Antioxidative [1,14,30,32]. } \\
\text { ROS scavenging [1,30]. } \downarrow \text { NOS } \\
\text { and peroxide [30]. } \\
\downarrow \text { UVR-induced antioxidant } \\
\text { enzyme depletion [30]. } \downarrow \\
\text { UVR-induced lipid peroxidase } \\
\text { and protein oxidation [30]. } \\
\text { Synergistic with } \\
\alpha \text {-lipoic acid [32]. }\end{array}$ \\
\hline
\end{tabular}


Table 2. Cont.

\begin{tabular}{|c|c|c|c|c|c|c|c|c|c|}
\hline $\begin{array}{l}\text { Skin Damage Form: } \\
\text { Mechanism/Effect }\end{array}$ & Probiotics & $\begin{array}{l}\text { Flavonoids } \\
\text { Quercetin }\end{array}$ & $\begin{array}{c}\text { Phenolic Acids } \\
\text { Caffeic, Ferulic, \& } \\
\text { Gallic Acids, Rutin }\end{array}$ & $\begin{array}{c}\text { Stilbenes } \\
\text { Resveratrol } \\
\text { Silibinin (Silymarin) }\end{array}$ & $\begin{array}{c}\text { Vitamin E } \\
\text { Tocotrienols }\end{array}$ & $\begin{array}{l}\text { Carotenoids } \\
\text { Tomato Derived }\end{array}$ & Coenzyme Q10 & $\begin{array}{l}\text { Eicosa-Pentaenoic } \\
\text { Acid (EPA) }\end{array}$ & $\begin{array}{c}\text { Green Tea } \\
\text { Epigallocatechin-3-gallate }\end{array}$ \\
\hline \multicolumn{5}{|c|}{ Ultraviolet Radiation (UVR) } & \multicolumn{5}{|c|}{ Ultraviolet Radiation (UVR) } \\
\hline $\begin{array}{l}\text { Photocarcinogenesis: } \\
\text { DNA mutation induction } \\
\rightarrow \text { immune } \\
\text { suppression }\end{array}$ & - & Anticancer [14]. & 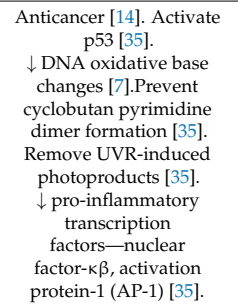 & $\begin{array}{c}\text { Anticancer }[1,4,414,37] \\
\downarrow \text { pro-inflammatory } \\
\text { transcription } \\
\text { factors-nuclear } \\
\text { factor- } \beta \text {, } \\
\text { mitogen-activated } \\
\text { protein kinases, AP-1 } \\
{[4,37] .}\end{array}$ & $\begin{array}{c}\downarrow \text { DNA damage [44]. } \\
\downarrow \text { pro-inflammatory } \\
\text { transcription } \\
\text { factors-nuclear } \\
\text { factor- } \kappa \beta \text {, signal } \\
\text { transducer and } \\
\text { activation of } \\
\text { transcription }[43,44]\end{array}$ & $\begin{array}{l}\downarrow \text { Mitochondrial DNA } \\
\text { mutations [50]. }\end{array}$ & $\begin{array}{l}\downarrow \text { UVR-induced DNA } \\
\text { damage [42]. }\end{array}$ & $\begin{array}{l}\text { EPA } \downarrow \\
\text { UVR-induced p53 } \\
\text { activity, DNA } \\
\text { single-strand } \\
\text { breaks, and DNA } \\
\text { oxidative base } \\
\text { changes [52]. }\end{array}$ & $\begin{array}{c}\text { Anticancer }[1,14,30,32] . \\
\uparrow \text { DNA repair enzyme } \\
\text { activity [1,30]. } \\
\downarrow \text { UVR- induced DNA oxidative } \\
\text { base changes [30]]. nuclear } \\
\text { factor- } \alpha \beta, A P-1[6,30,31] .\end{array}$ \\
\hline $\begin{array}{l}\text { Photocarcinogenesis: } \\
\text { Cell cycle and cellular } \\
\text { integrity impairment }\end{array}$ & - & - & $\begin{array}{l}\downarrow \downarrow \text { cytoskeletal disarray \& } \\
\text { MMP [35]. Maintain cell } \\
\text { viability [35]. }\end{array}$ & $\begin{array}{l}\downarrow \text { MMP [37]. Induces } \\
\text { p53-mediated } \\
\text { apoptosis [37]. }\end{array}$ & $\begin{array}{l}\text { Tcell cycle inhibitory } \\
\text { protein, } \\
\text { caspase-dependent, } \\
\text { and independent } \\
\text { apoptosis, } \\
\downarrow \text { cyclin dependent } \\
\text { kinase }[43] \text {. }\end{array}$ & $\begin{array}{l}\downarrow \text { UVR-induced } \\
\text { MMP [48,50]. }\end{array}$ & $\downarrow$ UVR-induced MMP [42]. & - & $\begin{array}{c}\downarrow \text { UVR-induced MMP }[1,31-33] \\
\downarrow \downarrow \text { UVR-induced signaling } \\
\text { protein phosphorylation [30]. }\end{array}$ \\
\hline \multicolumn{5}{|c|}{ Immunologic disease: Atopic dermatitis (AD) } & \multicolumn{5}{|c|}{ Immunologic Disease: Atopic Dermatitis } \\
\hline Immunologic changes & $\begin{array}{c}\text { Oral probiotics directly affect } \\
\text { Peyer's patch M-cells and } \\
\text { intestinal macrophages and } \\
\text { dendritic cellls [21]. Modulate } \\
\text { T-regulatory \& T-helper cell } \\
\text { 1\&2, cytokine, and IgA } \\
\text { responses [9, 12,25,27]. } \\
\text { Stimulate adaptive T-cell } \\
\text { maturation [25]. Favor a } \\
\text { non-atopic state via } \\
\text { microbiota shifts [5,12,25,27]. } \\
\downarrow \text { IgE-associated allergic } \\
\text { diseases-extrinsic AD } \\
\text { [9,12,27]. }\end{array}$ & - & - & - & - & - & - & - & Anti-inflammatory [31]. \\
\hline $\begin{array}{l}\text { Dehydrated skin: } \\
\uparrow \text { transepidermal } \\
\text { water loss }\end{array}$ & $\begin{array}{c}\text { Improves barrier function [5]. } \\
\downarrow \text { transepidermal water } \\
\text { loss [5]. }\end{array}$ & - & - & - & - & - & - & - & - \\
\hline $\begin{array}{l}\text { Dehydrated skin: } \\
\uparrow \text { stratum corneum } \\
\text { thickness }\end{array}$ & $\begin{array}{l}\downarrow \text { stratum corneum } \\
\text { thickness }[5] .\end{array}$ & & & & - & - & - & - & - \\
\hline $\begin{array}{l}\text { Dehydrated skin: } \uparrow \\
\text { opportunistic infections }\end{array}$ & $\begin{array}{c}\downarrow \text { opportunistic } \\
\text { infections [110]. } \\
\downarrow \text { bacterial load [28]. } \\
\text { Competitively exclude } \\
\text { pathogens from } \\
\text { keratinocytes [8]. }\end{array}$ & Anti-microbial [16]. & Antimicrobial [40]. & - & Antibacterial [45]. & - & - & - & Antimicrobial [31]. \\
\hline $\begin{array}{l}\text { Severity Scoring of } \\
\text { Atopic Dermatitis } \\
\text { Index }\end{array}$ & $\begin{array}{l}\downarrow \text { by Lactobacillus rhamnosus } \\
\text { GG or LL.fermentum } \\
\text { VRI-003 [ [n]. } \\
\downarrow \text { by mixed strain use in } \\
\leq 1 \text {-year-olds [24]. }\end{array}$ & - & - & - & - & - & - & - & - \\
\hline
\end{tabular}


Table 2. Cont.

\begin{tabular}{|c|c|c|c|c|c|c|c|c|c|}
\hline $\begin{array}{l}\text { Skin Damage Form: } \\
\text { Mechanism/Effect }\end{array}$ & Probiotics & $\begin{array}{l}\text { Flavonoids } \\
\text { Quercetin }\end{array}$ & $\begin{array}{c}\text { Phenolic Acids } \\
\text { Caffeic, Ferulic, \& } \\
\text { Gallic Acids, Rutin }\end{array}$ & $\begin{array}{c}\text { Stilbenes } \\
\text { Resveratrol } \\
\text { Silibinin (Silymarin) }\end{array}$ & $\begin{array}{c}\text { Vitamin E } \\
\text { Tocotrienols }\end{array}$ & $\begin{array}{c}\text { Carotenoids } \\
\text { Tomato Derived }\end{array}$ & Coenzyme Q10 & $\begin{array}{l}\text { Eicosa-Pentaenoic } \\
\text { Acid (EPA) }\end{array}$ & $\begin{array}{c}\text { Green Tea } \\
\text { Epigallocatechin-3-gallate }\end{array}$ \\
\hline \multicolumn{5}{|c|}{ Trauma-Thermal burns } & \multicolumn{5}{|c|}{ Trauma-Thermal burns } \\
\hline $\begin{array}{l}\text { Impaired wound } \\
\text { healing }\end{array}$ & 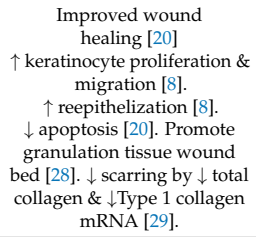 & - & - & - & - & - & - & - & - \\
\hline $\begin{array}{c}\uparrow \text { opportunistic } \\
\text { infections }\end{array}$ & 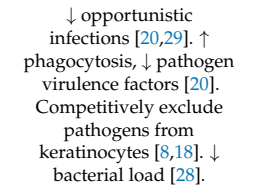 & Anti-microbial [16]. & Antimicrobial [40]. & - & Antibacterial [45]. & - & - & - & - \\
\hline
\end{tabular}

$\mathrm{AD}$, atopic dermatitis; AP-1, nuclear activation protein-1; IgA, immunoglobulin A; IgE, immunoglobulin E; MED, minimal erythemal dose; MMP, matrix metalloproteinases; NOS, nitric oxide synthase; NRF, nuclear factor E2-related factor 2; ROS, reactive oxygen species; UVR, ultraviolet radiation. 
Orally consumed $2.1 \%$ L. plantarum K8 lysates are skin moisturizers, which increase facial skin hydration through eight weeks of use $(p=0.007)$, decrease the horny layer thickness of the forearm and face through eight weeks of use ( $p=0.000$ for the face and forearm), and decrease TEWL of the forearm and face at eight weeks ( $p=0.002$ and $p=0.008$, respectively) [5]. Therefore, orally consumed $2.1 \%$ L. plantarum $\mathrm{K} 8$ lysates should reduce the need for topical corticosteroids and emollients for $\mathrm{AD}$ treatment [5]. Decreased horny layer thickness is important since this denotes a shift towards normal skin $[5,8]$. Given some directly equivalent outcomes to topical silver sulphadiazine, topical L. plantarum is a candidate for further larger scale in vivo study as a topical burn treatment $[28,29]$. Ideally, probiotic exposure should precede or be concurrent with pathogen exposure. Probiotic exposure after pathogen exposure may not prevent opportunistic infections $[8,18]$.

Live or lysate probiotic preparations are biologically plausibly efficacious where heat-killed preparations are ineffective $[8,18]$. Live cultures can competitively deplete the pathogens' nutrients. Live cultures are more proficient with competitive receptor binding and receptor binding displacers than are heat-killed or heat-inactivated substances $[8,18]$. As with heat-inactivated LGG for AD amelioration, heat-killed L. reuteri ATCC 55730 for S. aureus opportunistic infection ensures the effectiveness of the non-denatured probiotic $[9,18]$. Therefore, it has been recommended that probiotics or lysates, but not heat-inactivated substances, become components of barrier creams and soaps used by persons with propensity for skin disruption to reduce pathogenic microbe skin colonization and ensuing opportunistic infections [11].

Oral and topical polyphenols hold the photoprotection and anti-photocarginogenesis promise. Additional human trials on GTC and EGCG are needed. Formulations with improved GTC and EGCG bioavailability such as combinations with $\alpha$-lipoic acid may allow anti-inflammatory photo protective effectiveness at doses equivalent to less than 10 cups of green tea daily $[6,30,32]$. Historic bioactivity work on vitamin $\mathrm{E}$ focused on $\alpha$-tocopherol by discounting the role of tocotrienols. However, there is a growing body of literature that indicates that tocotrienols have powerful anti-inflammatory photoprotection activity and lipophilic penetration into the brain and liver distinct from tocopherols $[43,44]$. Therefore, the need to study full spectrum palm oil vitamin $\mathrm{E}$ and water-soluble phenolic-flavonoid-rich antioxidant complex and carotenoids further is supported by the literature [47]. Similarly, quercetin, resveratrol, silymarin, and grape seed proanthocyanidins should progress from murine to human trials. Larger scale human trials of $\beta$-carotene, lycopene, and lutein with tomato phytonutrients, coenzyme Q10, and EPA should be considered.

Supplementary Materials: The following are available online at http:/ /www.mdpi.com/2227-9032/6/2/40/s1, Abbreviations List.

Author Contributions: O.N. conceived and designed the commentary, performed the literature search, analyzed the retrieved articles, and wrote the commentary.

Acknowledgments: This is an independent, unfunded work. This work is based on an oral presentation at the 9th International Conference and Exhibition on Chinese Medicine, Ayurveda \& Acupuncture Barcelona, Spain, 12-13 March 2018.

Conflicts of Interest: The author declares no conflict of interest.

\section{References}

1. Nichols, J.A.; Katiyar, S.K. Skin photoprotection by natural polyphenols: Anti-inflammatory, anti-oxidant and DNA repair mechanisms. Arch. Dermatol. Res. 2010, 302, 71-83. [CrossRef] [PubMed]

2. Apalla, Z.; Lallas, A.; Sotiriou, E.; Lazaridou, E.; Ioannides, D. Epidemiological trends in skin cancer. Dermatol. Pract. Concept. 2017, 7, 1-6. [CrossRef] [PubMed]

3. Lomas, A.; Leonardi-Bee, J.; Bath-Hextall, F. A systematic review of worldwide incidence of nonmelanoma skin cancer. Br. J. Dermatol. 2012, 166, 1069-1080. [CrossRef] [PubMed]

4. Vaid, M.; Katiyar, S.K. Molecular mechanisms of inhibition of photocarcinogenesis by silymarin, a phytochemical from milk thistle (Silybum marianum L. Gaertn). Int. J. Oncol. 2010, 36, 1053-1060. [PubMed] 
5. Kim, H.; Kim, H.R.; Jeong, B.J.; Lee, S.S.; Kim, T.R.; Jeong, J.H.; Lee, M.; Lee, S.; Lee, J.S.; Chung, D.K. Effects of oral intake of kimchi-derived Lactobacillus plantarum K8 lysates on skin moisturizing. J. Microbiol. Biotechnol. 2015, 25, 74-80. [CrossRef] [PubMed]

6. Farrar, M.D.; Nicolaou, A.; Clarke, K.A.; Mason, S.; Massey, K.A.; Dew, T.P.; Watson, R.E.B.; Williamson, G.; Rhodes, L.E. A randomized controlled trial of green tea catechins in protection against ultraviolet radiation-induced cutaneous inflammation. Am. J. Clin. Nutr. 2015, 102, 608-615. [CrossRef] [PubMed]

7. Chaiprasongsuk, A.; Onkoksoong, T.; Pluemsamran, T.; Limsaengurai, S.; Panich, U. Photoprotection by dietary phenolics against melanogenesis induced by UVA through Nrf2-dependent antioxidant responses. Redox Biol. 2016, 8, 79-90. [CrossRef] [PubMed]

8. Mohammedsaeed, W. Characterisation of the Potential of Probiotics or Their Extracts as Therapy for Skin. Doctor of Philosophy Thesis, The University of Manchester, Manchester, UK, 12 March 2014. Available online: https://www.research.manchester.ac.uk/portal/files/54569801/FULL_TEXT.PDF (accessed on 5 March 2018).

9. Da Costa Baptista, I.P.; Accioly, E.; de Carvalho Padilha, P. Effect of the use of probiotics in the treatment of children with atopic dermatitis; a literature review. Nutr. Hosp. 2013, 28, 16-26. [PubMed]

10. Powers, C.E.; McShane, D.B.; Gilligan, P.H.; Burkhart, C.N.; Morrell, D.S. Microbiome and pediatric atopic dermatitis. J. Dermatol. (Japan) 2015, 42, 1137-1142. [CrossRef] [PubMed]

11. Okada, H.; Kuhn, C.; Feillet, H.; Bach, J.-F. The "hygiene hypothesis" for autoimmune and allergic diseases: An update. Clin. Exp. Immunol. 2010, 160, 1-9. [CrossRef] [PubMed]

12. Van der Aa, L.B.; Heymans, H.S.A.; van Aalderen, W.M.C.; Sprikkelman, A.B. Probiotics and prebiotics in atopic dermatitis: Review of the theoretical background and clinical evidence. Pediatr. Allergy Immunol. 2010, 21, e355-e367. [CrossRef] [PubMed]

13. Flohr, C.; Henderson, A.J.; Kramer, M.S.; Patel, R.; Thompson, J.; Rifas-Shiman, S.L.; Yang, S.; Vilchuck, K.; Bogdanovich, N.; Hameza, M.; et al. Effect of an intervention to promote breastfeeding on asthma, lung function, and atopic eczema at age 16 years. Follow-up of the PROBIT randomized trial. JAMA Pediatr. 2018, 172, e174064. [CrossRef] [PubMed]

14. Sauer, S.; Plauth, A. Health-beneficial nutraceuticals-Myth or reality? Appl. Microbiol. Biotechnol. 2017, 101, 951-961. [CrossRef] [PubMed]

15. Mondello, L. Nutraceuticals and separations. Anal. Bioanal. Chem. 2013, 405, 4589-4590. [CrossRef] [PubMed]

16. Ratz-Lyko, A.; Arct, J.; Majewski, S.; Pytkowska, K. Influence of polyphenols in the physiological processes in the skin. Phytother. Res. 2015, 29, 509-517. [CrossRef] [PubMed]

17. Pérez-Sánchez, A.; Barrajon-Catalan, E.; Herranz-López, M.; Micol, V. Nutraceuticals for skin care: A comprehensive review of human clinical studies. Nutrients 2018, 10, 403. [CrossRef] [PubMed]

18. Prince, T.; McBain, A.J.; O'Neill, C.A. Lactobacillus reuteri protects epidermal keratinocytes from Staphylococcus aureus-induced cell death by competitive exclusion. Appl. Environ. Microbiol. 2012, 78, 5119-5126. [CrossRef] [PubMed]

19. Costeloe, K.L.; Bowler, U.; Brocklehurst, P.; Hardy, P.; Heal, P.; Juszczak, E.; King, A.; Panton, N.; Stacey, F.; Whiley, A.; et al. A randomised controlled trial of the probiotic Bifidobacterium breve BBG-001 in preterm babies to prevent sepsis, necrotising enterocolitis and death: The probiotics in preterm infants (PiPS) trial. Health Technol. Assess. 2016, 20,1-194. [CrossRef] [PubMed]

20. Valdéz, J.C.; Peral, M.C.; Rachid, M.; Santana, M.; Perdigón, G. Interference of Lactobacillus plantarum with Pseudomonas aeruginosa in vitro and in infected burns: The potential use of probiotics in wound treatment. Clin. Microbiol. Infect. 2005, 11, 472-479. [CrossRef] [PubMed]

21. West, N.P.; Pyne, D.B.; Peake, J.M.; Cripps, A.W. Probiotics, immunity and exercise: A review. Exerc. Immunol. Rev. 2009, 15, 107-126. [PubMed]

22. Guéniche, A.; Bastien, P.; Ovigne, J.M.; Kermici, M.; Courchay, G.; Chevalier, V.; Breton, L.; Castiel-Higounenc, I. Bifidobacterium longum lysate, a new ingredient for reactive skin. Exp. Dermatol. 2010, 19, e1-e8. [CrossRef] [PubMed]

23. Garcia-Larsen, V.; Ierodiakonou, D.; Jarrold, K.; Cunha, S.; Chivinge, J.; Robinson, Z.; Geoghegan, N.; Ruparelia, A.; Devani, A.; Trivella, M.; et al. Diet during pregnancy and infancy and risk of allergic or autoimmune disease: A systematic review and meta-analysis. PLoS Med. 2018, 15, e1002507. [CrossRef] [PubMed] 
24. Chang, Y.-S.; Trivedi, M.K.; Jha, A.; Lin, Y.-F.; Dimaano, L.; García-Romero, M.T. Synbiotics for prevention and treatment of atopic dermatitis. A meta-analysis of randomized controlled clinical trials. JAMA Pediatr. 2016, 170, 236-242. [CrossRef] [PubMed]

25. Smith-Norowitz, T.A.; Bluth, M.H. Probiotics and diseases of altered IgE regulation: A short review. J. Immunotoxicol. 2016, 13, 136-140. [CrossRef] [PubMed]

26. Van der Aa, L.B.; Lutter, R.; Heymans, H.S.A.; Smids, B.S.; Dekker, T.; van Aalderen, W.M.C.; Sillevis Smitt, J.H.; Knippels, L.M.J.; Garssen, J.; Nauta, A.J.; et al. No detectable beneficial systemic immunomodulatory effects of specific symbiotic mixture in infants with atopic dermatitis. Clin. Exp. Allergy 2012, 42, 531-539. [CrossRef] [PubMed]

27. Kuitunen, M.; Kukkonen, K.; Juntunen-Backman, K.; Korpela, R.; Poussa, T.; Tuure, T.; Haahtela, T.; Savilahti, E. Probiotics prevent IgE-associated allergy until age 5 years in cesarean-delivered children but not in the total cohort. J. Allergy Clin. Immunol. 2009, 123, 335-341. [CrossRef] [PubMed]

28. Peral, M.C.; Martinez, M.A.; Valdez, J.C. Bacteriotherapy with Lactobacillus plantarum in burns. Int. Wound J. 2009, 6, 73-81. [CrossRef] [PubMed]

29. Satish, L.; Gallo, P.H.; Johnson, S.; Yates, C.C.; Kathju, S. Local Probiotic Therapy with Lactobacillus plantarum mitigates scar formation in rabbits after burn injury and infection. Surg. Infect. 2017, 18, 119-127. [CrossRef] [PubMed]

30. OyetakinWhite, P.; Tribout, H.; Baron, E. Protective mechanisms of green tea polyphenols in skin. Oxid. Med. Cell. Longev. 2012, 2012. [CrossRef] [PubMed]

31. Zink, A.; Traidl-Hoffman, C. Green tea in dermatology-Myths and facts. JDDG 2015, 13, 768-775. [CrossRef] [PubMed]

32. Scalia, S.; Marchetti, N.; Bianchi, A. Comparative evaluation of different co-oxidants on the photochemicaland functional-stability of epigallocatechin-3-gallate in topical creams exposed to simulated sunlight. Molecules 2013, 18, 574-587. [CrossRef] [PubMed]

33. Saric, S.; Sivamani, R.K. Polyphenols and Sunburn. Int. J. Mol. Sci. 2016, 17, 1521. [CrossRef] [PubMed]

34. Peres, D.A.; de Oliveira, C.A.; da Costa, M.S.; Tokunaga, V.K.; Mota, J.P.; Rosado, C.; Consiglieri, V.O.; Kaneko, T.M.; Velasco, M.V.R.; Baby, A.R. Rutin increases critical wavelength of systems containing a single UV filter and with good skin compatibility. Skin Res. Technol. 2016, 22, 325-333. [CrossRef] [PubMed]

35. El-Haj, N.; Goldstein, N. Sun protection in a pill: The photoprotective properties of Polypodium leucotomas extract. Int. J. Dermatol. 2015, 54, 362-366. [CrossRef] [PubMed]

36. Tuong, W.; Kuo, S.; Sivamani, R.K. Photoprotective effect of botanicals and vitamins: A systematic review of clinical trials. J. Dermatol. Treat. 2015, 26, 558-570. [CrossRef] [PubMed]

37. Ndiaye, M.; Philippe, C.; Mukhtar, H.; Ahmad, N. The Grape Antioxidant Resveratrol for Skin Disorders: Promise, Prospects, and Challenges. Arch. Biochem. Biophys. 2011, 508, 164-170. [CrossRef] [PubMed]

38. Katiyar, S.K. Grape seed proanthocyanidines and skin cancer prevention: Inhibition of oxidative stress and protection of immune system. Mol. Nutr. Food Res. 2008, 52, S71-S76. [CrossRef] [PubMed]

39. Breton, L.; Liviero, C.; Fagot, D. Skin Toning by Stimulating Collagen Synthesis/Proliferation of Dermal Fibroblasts. United States Patent 6147121, 14 November 2000. Available online: http:/ /www.everypatent. com/comp/pat6147121.html (accessed on 4 March 2018).

40. Vitonyte, J.; Manca, M.L.; Caddeo, C.; Valenti, D.; Peris, J.E.; Usach, I.; Nacher, A.; Matos, M.; Gutiérrez, G.; Orrù, G.; et al. Bifunctional viscous nanovesicles co-loaded with resveratrol and gallic acid for skin protection against microbial and oxidative injuries. Eur. J. Pharm. Biopharm. 2017, 114, 278-287. [CrossRef] [PubMed]

41. Liu, W.; Otkur, W.; Li, L.; Wang, Q.; He, H.; Ye, Y.; Zhang, Y.; Hayashi, T.; Tashiro, S.; Onodera, S.; et al. Autophagy induced by silibinin protects human epidermoid carcinoma A431 cells from UVB-induced apotosis. J. Photochem. Photobiol. B Biol. 2013, 123, 23-31. [CrossRef] [PubMed]

42. Godic, A.; Poljšak, B.; Adamic, M.; Dahmane, R. The Role of Antioxidants in Skin Cancer Prevention and Treatment. Oxid. Med. Cell. Longev. 2014, 2014, 860479. [CrossRef] [PubMed]

43. Ahsan, H.; Ahad, A.; Iqbal, J.; Siddiqui, W.A. Pharmacological potential of tocotrienols: A review. Nutr. Metab. (Lond.) 2014, 11, 52. [CrossRef] [PubMed]

44. Vasanthi, H.R.; Parameswari, R.P.; Das, D.K. Multifaceted role of tocotrienols in cardioprotection supports their structure: Function relation. Genes. Nutr. 2012, 7, 19-28. [CrossRef] [PubMed]

45. Sundram, K.; Sambanthamurthi, R.; Tan, Y.A. Palm fruit chemistry and nutrition. Asia Pac. J. Clin. Nutr. 2003, 12, 355-362. [PubMed] 
46. Brownlow, B.; Nagaraj, V.J.; Nyel, A.; Joshi, M.; Elbayoumi, T. Development and in vitro evaluation of vitamin E-enriched nanoemulsion vehicles loaded with genistein for chemoprevention against UVB-induced skin damage. Pharm. Nanotechnol. 2015, 104, 3510-3523. [CrossRef] [PubMed]

47. Stahl, W.; Heinrich, U.; Jungmann, H.; Sies, H.; Tronnier, H. Carotenoids and carotenoids plus vitamin E protect against ultraviolet light-induced erythema in humans. Am. J. Clin. Nutr. 2000, 71, 795-798. [CrossRef] [PubMed]

48. Grether-Beck, S.; Marini, A.; Jaenicke, T.; Stahle, W.; Krutmann, J. Molecular evidence that oral supplementation with lycopene or lutein protects human skin against ultraviolet radiation: Results from a double-blind, placebo-controlled, crossover study. BJD 2016, 176, 1231-1240. [CrossRef] [PubMed]

49. Marini, A.; Jaenicke, T.; Grether-Beck, S.; Le Floc'h, C.; Cheniti, A.; Piccardi, N.; Krutmann, J. Prevention of polymorphic light eruption by oral administration of a nutritional supplement containing lycopene, $\beta$-carotene, and Lactobacillus johnsonii: Results from a randomized, placebo-controlled, doubleblinded study. Photodermatol. Photoimmunol. Photomed. 2014, 30, 189-194. [CrossRef] [PubMed]

50. Rizwan, M.; Rodriguez-Blanco, A.; Harbottle, A.; Birch-Machin, M.A.; Watson, R.E.B.; Rhodes, L.E. Tomato paste rich in lycopene protects against cutaneous photodamage in humans in vivo: A randomized controlled trial. BJD 2010, 164, 154-162. [CrossRef] [PubMed]

51. Zmitek, K.; Pogacnik, T.; Mervic, L.; Zmitek, J.; Pravst, I. The effect of dietary intake of coenzyme Q10 on skin parameter and condition: Results of a randomised, placebo-controlled, double-blind study. BioFactors 2017, 43, 132-140. [CrossRef] [PubMed]

52. Rhodes, L.E.; Shahbakhti, H.; Azurdia, R.M.; Moison, R.M.W.; Steenwinkel, M.-J.S.T.; Homburg, M.I.; Dean, M.P.; McArdle, F.; Beijersbergen van Henegouwen, G.M.J.; Epe, B.; et al. Effect of eicosapentaenoic acid, an omega-3 olyunsaturated fatty acid, on UVR-related cancer risk in humans. An assessment of early genotoxic markers. Carcinogenesis 2003, 24, 919-925. [CrossRef] [PubMed]

53. Jackson, M.J.; McArdle, F.; Storey, A.; Jones, S.A.; McArdle, A.; Rhodes, L.E. Effects of micronutrient supplements on u.v.-induced skin damage. Proc. Nutr. Soc. 2002, 61, 187-189. [CrossRef] [PubMed]

(C) 2018 by the author. Licensee MDPI, Basel, Switzerland. This article is an open access article distributed under the terms and conditions of the Creative Commons Attribution (CC BY) license (http:/ / creativecommons.org/licenses/by/4.0/). 